\title{
THE EFFECT OF HEARING LOSS ON THE SIBLING RELATIONSHIP
}

\author{
A. Sanem Sahli, Erol Belgin
}

Hacettepe University, Faculty of Medicine, Department of Otorhinolaryngology, Head and Neck Surgery, Audiology and Speech Pathology Section, Ankara, Turkey

\begin{abstract}
Aim: The aim of the study was to analyze the brother or sister bond in individuals whose siblings have hearing loss, and to see whether variables such as age, sex, age-difference of siblings, and family characteristic affected the relationship.

Materials and Methods: This study included 20 individuals who had normal-hearing siblings and 20 individuals who had hearing-impaired siblings. The latter were children and adolescents of the Training Unit of Hearing and Speaking Abilities at Hacettepe University, Department of ENT, Audiology and Speech Pathology Section, Turkey. The siblings in question were over 12 and had normal hearing. A 'General Information Form' was used to gather information about the individuals who participated in the study and their hearing-loss siblings; a 'Sibling Relationship Questionnaire' was used to gauge relationships between siblings.

Results: In general, individuals having a sibling with hearing loss had considerably higher scores on the subscales warmth/ closeness and relative power/status than those having normal-hearing siblings $(p<0.05)$. Likewise, individuals having normalhearing siblings had higher scores on the subscales "conflict" and "rivalry" than those in the other group $(p<0.05)$.

Conclusions: Existence of a hearing-impaired child in the family affects the sibling relationship. Growing up with a hearingimpaired sibling brings changes to the daily life of normal children. Individuals having a sibling with hearing loss have less conflict and rivalry and more intimacy/fondness in their sibling relationship. We infer that these children have developed an ability to help their siblings.
\end{abstract}

Keywords: hearing loss • sibling • personal relationships • children

\section{АНАЛИЗ ОТНОШЕНИЙ СИБСОВ, ОДИН ИЗ КОТОРЫХ ИМЕЕТ СЛУХОВОЙ АППАРАТ ИЛИ КОХЛЕАРНЫЙ ИМПЛАНТАТ}

\section{Резюме}

Цель: Главная цель этого обзора состоит в том, чтобы проанализировать родственные отношения сибсов, когда один из них имеет нарушения слуха, и определить, влияют ли такие факторы как, на пример, возраст, пол, возрастные различия и семейные особенности на отношения между ними или нет.

\begin{abstract}
Материал и Методы: Это исследование включает в себя 20 человек, которые имеют единокровных братьев или сестер без нарушений слуха, а так же 20 детей и подростков, имеющих единокровных брата или сестру, которые проходят тренировку в Учебном Отделении Способностей Слышать и Говорить в Университете Хаджеттепе, Отделение ENT, Секция Аудиологии и Речевой Патологии. Опрашиваемые особы в возрасте не менее 12 лет не имеют никаких нарушений слуха. Были использованы «Анкета Общей Информации», целью которой было получение информации о участниках исследования и их единокровных братьях и сестрах, имеющих нарушения слуха, а так же «Анкета Отношений Сибсов», которая была направлена на определение характеристик отношений между братьями и сестрами.
\end{abstract}

Результаты: В конце исследования было выявлено, что особы в группе, имеющей сибсов с нарушениями слуха, получили значительно более высокие показатели по шкале, определяющей близость/любовь и родственный статус/прочность, чем те в группе, имеющие сибсов без физических недостатков (p<0.05). Напротив, опрашиваемые в группе, имеющие сибсов без нарушения слуха, получили более высокие показатели по шкале «конфликт» и «конкуренция», чем те в другой группе $(\mathrm{p}<0.05)$.

Заключение: Психологическая и педагогическая консультация должна быть проведена не только с ребенком с нарушениями слуха или его родителями, но так же с его сестрами и братьями в учреждениях для детей с нарушениями слуха. 


\title{
EL ANÁLISIS DE LAS RELACIONES DE HERMANOS UNO DE LOS CUALES TIENE UN IMPLANTE COCHLEAR O AUDÍFONO
}

\begin{abstract}
o
Objetivo: El objetivo principal de esta revisión es analizar la hermandad de los individuos que tienen un hermano con sordera, y ver si algunos factores como edad, sexo, diferencia de edad de hermanos y características de la familia influyen en su relación o no.

Material y Método: Esta investigación incluye 20 individuos que no tienen un hermano con discapacidad auditiva y 20 hermanos de niños y adolescentes que son entrenados en la Unidad de Formación de Capacidades de Oído y Habla en la Universidad Hacettepe, Departamento de ENT, Sección de Audiología y Patología de Habla. Los hermanos que son cuestionados son más de 12 años y no tienen ninguna pérdida de audición. Fueron usados "Formulario de Información General" que tiene como objetivo recopilar información sobre los individuos que participan en el estudio y sus hermanos con la pérdida de audición, y "Cuestionario de Relación entre Hermanos" que tiene por objetivo determinar las calificaciones que se identifican hermandad.

Resultados: Se cree al final del estudio que los del grupo que tienen un hermano con sordera han obtenido las puntuaciones considerablemente más altas en las subescalas de la intimidad/cariño y la situación/la fuerza familiar que los del grupo que no tienen hermanos con discapacidad $(\mathrm{p}<0.05)$. Por el contrario, los del grupo que no tienen hermanos con sordera han ganado resultados muy superiores en las subescalas de "conflicto" y "rivalidad" que los del otro grupo $(\mathrm{p}<0.05)$.
\end{abstract}

Conclusión: Deberían dar la consulta psicológica y pedagógica no sólo al niño con problemas auditivos o el padre sino también a los hermanos en las instituciones que sirven a los niños con sordera.

Palabras clave: sordera $\bullet$ hermano $\bullet$ relaciones $\bullet$ niños

\section{Background}

Brotherhood and sisterhood are the longest relationships in life for most people. Since $80 \%$ of people in the society have at least one sibling, siblings play significant roles in the lives of many people [1]. Existence of a hearing-impaired child in the family affects the nature of the bond between brothers and sisters. Most mothers and fathers feel deep sorrow when they learn about their children's handicap. The other children in the family share the despair and they are sometimes affected negatively, although they cannot understand the feelings of their parents [2]. Growing up with a hearing-impaired sibling brings changes to daily life of the normal children and causes them difficulty in adaptation and development [3]. According to Dyson et al. (4), the handicap of the hearing-impaired child can affect the other children: lack of parental care, increased responsibility for caring for their sibling, pressures caused by the limitations of the handicapped sibling, labeling by society, loss of normal sibling interaction, and changes in family roles.

Researchers document that siblings often have negative feelings about having a handicapped sibling, such as guilt, shame, indifference, and feeling defective. These siblings tend to be more anxious and ranked on a lower level in the perceived efficiency in social acceptance and behavior [5]. Their behavioral problems are more intense [2], they think more about their future, they usually see their sibling as a burden, and the siblings of hearing-impaired children have more problematic attitudes [6]. The aim of our study was to analyze brotherhood and sisterhood of individuals who had a sibling with hearing loss, and to see whether some variables such as age, sex, age difference of siblings, and family characteristic influenced their relationship.

\section{Materials and Methods}

This study included 20 individuals who had a normalhearing sibling and 20 individuals who had a hearing-impaired sibling who were in the Training Unit of Hearing and Speaking Abilities in Hacettepe University, Department of ENT, Audiology and Speech Pathology Section, Turkey. The siblings in question were over 12 and had normal hearing. The selection of participants was done randomly. Also, the siblings and parents participating in the study were informed about the research and a "Volunteer Informing and Approval Form" was signed by them.

In our study we used a 'General Information Form' which gathers general information about the individuals who participated in the study and their siblings with hearing loss, and a 'Sibling Relationship Questionnaire' which identified qualities of the bond between brothers and sisters.

1. General Information Form asked questions about the socio-demographic conditions of the siblings and family of the child with a hearing loss (age, sex, age difference, family type, number of children, socio-economic status, etc.) and some questions about the child exhibiting the hearing loss.

2. Sibling Relationship Questionnaire (SRQ; Furman \& Buhrmester, 1985) is a self-report inventory that assesses relationships with closest-in-age siblings. The SRQ consists of 48 items covering 4 factors related to the siblings' 
Sahli A.S. and Belgin E. - The effect of hearing loss...

Table 1. Demographics of participants according to gender, age, age difference, and number of siblings.

\begin{tabular}{|c|c|c|c|c|}
\hline & \multicolumn{2}{|c|}{$\begin{array}{c}\text { Group having a sibling } \\
\text { with hearing loss }(n=20)\end{array}$} & \multicolumn{2}{|c|}{$\begin{array}{l}\text { Group with normal-hearing } \\
\text { sibling }(n=20)\end{array}$} \\
\hline & $n$ & $\%$ & $n$ & $\%$ \\
\hline \multicolumn{5}{|l|}{ Gender } \\
\hline Boy & 12 & 60 & 10 & 50 \\
\hline Girl & 8 & 40 & 10 & 50 \\
\hline \multicolumn{5}{|l|}{ Age } \\
\hline $12-16$ years & 12 & 60 & 9 & 45 \\
\hline $16-20$ years & 6 & 30 & 8 & 40 \\
\hline 20 and over & 2 & 10 & 3 & 15 \\
\hline \multicolumn{5}{|l|}{ Age difference } \\
\hline 5 years and below & 13 & 65 & 11 & 55 \\
\hline 5 years and over & 7 & 35 & 9 & 45 \\
\hline \multicolumn{5}{|l|}{ Number of siblings } \\
\hline $1-2$ & 17 & 85 & 14 & 70 \\
\hline 3 and over & 3 & 15 & 6 & 30 \\
\hline
\end{tabular}

Table 2. Distribution of siblings with hearing loss according to gender, age, and hearing technology.

\begin{tabular}{|c|c|c|}
\hline & $\boldsymbol{n}$ & \% \\
\hline Gender & & 55 \\
\hline Boy & 11 & 45 \\
\hline Girl & 9 & 25 \\
\hline Age & 5 & 40 \\
\hline 6 years and below & 8 & 35 \\
\hline 6-12 years & 7 & 25 \\
\hline 12 and over & & 75 \\
\hline Hearing technology & 5 & \\
\hline Hearing aid & 15 & \\
\hline Cochlear implant & & \\
\hline
\end{tabular}

relationship: Warmth/Closeness, Relative Power/Status, Conflict, and Rivalry. Warmth/Closeness in the sibling relationship is characterized by qualities such as intimacy, prosocial behavior, companionship, nurturance, and admiration. Relative Power/Status is conceptualized as the level of symmetry in the sibling relationship characterized by nurturance of sibling, nurturance by sibling, dominance of sibling, and dominance by sibling. Conflict/Rivalry is characterized by qualities such as quarreling, antagonism, competition, and struggles over dominance [7].

On each of the items, participants responded using a 5 -point Likert scale (from "hardly at all" to "extremely much"). Higher scores indicate a particular feature is more characteristic of the sibling relationship (e.g., "How much do you tell this sibling what to do?"; "How much do you and this sibling love each other?"). This instrument has found widespread use in assessing the quality of the sibling relationship. The internal consistency of the factor scales in this sample was $0.80,0.81,0.84$, and 0.74 , respectively. The SRQ-R factor scores have high test-retest reliability and have been validated for both school-aged children and adolescents $[7,8]$.

The participants filled in the information form and the questionaire with the researcher. The time spent filling out the form and questionnaire was about 45 minutes for each participant. SPSS (Statistical Package for Social 
Table 3. The average scores and standard deviations of groups according to 4 main subdimensions of SRQ.

\begin{tabular}{|c|c|c|c|c|}
\hline \multirow{2}{*}{ Subdimensions of SRQ } & \multicolumn{2}{|c|}{$\begin{array}{c}\text { Group having a sibling with hearing } \\
\text { loss }(\boldsymbol{n}=\mathbf{2 0})\end{array}$} & $\begin{array}{c}\text { Group having normal hearing sibling } \\
(\boldsymbol{n}=\mathbf{2 0})\end{array}$ \\
\cline { 2 - 5 } & $\mathbf{X}$ & $\mathbf{S D}$ & $\mathbf{X}$ & SD \\
\hline Warmth/Closeness & 78.19 & 9.13 & 74.15 & 11.34 \\
\hline Relative Power/Status & 37.61 & 6.75 & 33.25 & 6.95 \\
\hline Conflict & 19.65 & 5.88 & 24.82 & 5.47 \\
\hline Rivalry & 14.75 & 3.16 & 18.15 & 2.89 \\
\hline
\end{tabular}

$\mathrm{X}$ - mean; SD - standard deviation.

Table 4. The average scores and standard deviations of groups according to 4 main subdimensions of SRQ by gender.

\begin{tabular}{|c|c|c|c|c|c|c|}
\hline Groups & Gender & X/SD & $\begin{array}{l}\text { Warmth/ } \\
\text { Closeness }\end{array}$ & $\begin{array}{c}\text { Relative Power/ } \\
\text { Status }\end{array}$ & Conflict & Rivalry \\
\hline \multirow{4}{*}{$\begin{array}{c}\text { Group having } \\
\text { a sibling with hearing } \\
\text { loss }(n=20)\end{array}$} & \multirow{2}{*}{ Girl } & $x$ & 78.75 & 37.56 & 18.32 & 14.15 \\
\hline & & SD & 11.56 & 5.45 & 6.75 & 3.65 \\
\hline & \multirow{2}{*}{ Boy } & $x$ & 73.25 & 33.45 & 21.45 & 17.47 \\
\hline & & SD & 12.68 & 6.77 & 5.92 & 2.63 \\
\hline \multirow{4}{*}{$\begin{array}{l}\text { Group having } \\
\text { normal hearing } \\
\text { sibling }(n=20)\end{array}$} & \multirow{2}{*}{ Girl } & $x$ & 75.80 & 36.72 & 23.65 & 17.98 \\
\hline & & SD & 11.82 & 7.43 & 6.41 & 2.55 \\
\hline & \multirow{2}{*}{ Boy } & $x$ & 69.90 & 32.87 & 25.87 & 19.37 \\
\hline & & SD & 10.15 & 6.32 & 5.75 & 3.01 \\
\hline
\end{tabular}

$\mathrm{X}$ - mean; SD - standard deviation.

Sciences) Version 15.0 for Windows was used, and percentage, frequency distributions, average scores, standard deviation, and faults were evaluated in the data analysis process. T-test, correlation, and unidirectional analysis of variance were used in group comparisons and relevance.

\section{Results}

When we investigated the socio-demographic conditions of the siblings who participated in the study we found that $60 \%(n=12)$ of those having a sibling with hearing loss were boys and $40 \%(n=8)$ were girls, and $50 \%(n=10)$ of those who had normal-hearing sibling were boys and $50 \%(n=10)$ were girls. Some $60 \%(n=12)$ of those having a sibling with hearing loss were aged between 12 and 16 , $30 \%(n=6)$ were aged between 16 and $20,10 \%(n=2)$ were aged 20 or over. In comparison, $45 \%(n=9)$ of those having a normal-hearing sibling were aged between 12 and 16 , $40 \%(n=8)$ were aged between 16 and 20 , and $15 \%(n=3)$ were aged 20 or over (Table 1 ).

When we analyzed the sex of siblings exhibiting hearing loss, $55 \%(n=11)$ were boys and $45 \%(n=9)$ were girls. In terms of age, $25 \%(n=5)$ were younger than $6,40 \%(n=8)$ were between 6 and 12, and 35\% $(n=7)$ were older than 12. Moreover, 15 of these siblings (75\%) used cochlear implant, and 5 of them (25\%) used hearing aids (Table 2). When the age difference of siblings was considered, we see that the age difference of 13 of the individuals in the group who had a sibling with hearing loss (65\%) is less than 5 years, while 7 of them (35\%) had an age difference of more than 5 years. In the group having a normal-hearing sibling, the age difference of 11 of the siblings (55\%) is less than 5 years while 9 of them (45\%) had an age difference of more than 5 years (Table 1).

Table 1 also shows that 16 of the individuals who had a sibling with hearing loss $(80 \%)$ had an immediate family and 4 of them (20\%) had an extended family, whereas 15 of the individuals who had a normal-hearing sibling (75\%) had an immediate family and 5 of them (25\%) had an extended family when the family structure of the siblings is examined. Furthermore, the number of siblings in 17 of the individuals who had a sibling with hearing loss (85\%) was at least 2 , and the number of siblings in 3 of them (15\%) was 3 or more. The number of siblings in 14 of the individuals who had a normal-hearing sibling (70\%) was at least 2, and the number of siblings in 6 of them $(30 \%)$ was 3 or more (Table 1$)$. All the families attending this study had an average socio-economic status.

At the end of the study, significant differences were found between the group having a sibling with hearing loss and the group having normal hearing siblings. This was true for all scores gathered from the 4 main sub-dimensions of the Sibling Relationship Questionnaire (Warmth/Closeness, Relative Power/Status, Conflict, and Rivalry). The average scores and standard deviations are shown in Table 3. 
When we inspect Table 3, the group having a sibling with hearing loss have significantly higher scores in the sub scales of warmth/closeness and relative power/status than the group having a normal hearing sibling $(p<0.05)$. On the contrary, the ones in the group having normal hearing sibling have significantly higher scores from the sub scales "conflict" and "rivalry" than the group having a sibling with hearing loss $(p<0.05)$.

In this study, the girls in both groups have higher scores in the warmth/closeness and relative power/status sub dimensions than the boys, and this is significant statistically $(p<0.05)$. The boys in both groups have higher scores in conflict and rivalry sub dimensions, but this is not significant statistically ( $p>0.05)$. (Table 4$)$. In addition, a statistically significant difference was not found between the two groups with respect to the variables of age, age difference of siblings, family type, and number of siblings $(p>0.05)$, and these variables do not have a meaningful effect on the scores.

\section{Conclusions}

Individuals who do not have a sibling with hearing loss have higher scores in conflict and rivalry sub dimensions than those having a sibling with hearing loss. This finding is similar to those in the literature where individuals having a sibling with hearing loss have less conflict and rivalry than those having a normal-hearing sibling [9].
Importantly, however, our study shows that individuals having a sibling with hearing loss have higher scores in the warmth/closeness and relative power/status sub dimensions. The sibling's handicap apparently helps the sibling without the handicap to develop abilities in helping and tolerance [10]. The findings of our study also show that children having a sibling with hearing loss have less conflict and rivalry and more warmth/closeness in their sibling relationships and we infer that these children's abilities of helping their siblings have developed.

Individuals having a sibling with hearing loss have higher scores in the "Relative Power/Status" sub dimension than those in the comparison group. Items which relate to the sub dimensions of training the sibling, being trained by the sibling, dominance over the sibling, and dominance of the sibling fall into the "Relative Power/Status" sub dimension. Elder siblings who have a handicapped sibling undertake more responsibilities in terms of teaching, helping, and guiding than the individuals having no sibling with hearing loss, according to the surveys conducted [11-13].

The family needs to be dealt with as a whole when services are given to the child with hearing loss. Brotherhood and sisterhood are important relationships because of their effect on the social and emotional atmosphere in which the child grows up. The psycho-social abilities gained as a result of sibling interactions are used later in life in social relationships with other people [14].

\section{References:}

1. Dunn J: Sisters and brothers: current issues in developmental research. In: Children's Sibling Relationships: Developmental and Clinical Issues. Dunn J, Boer F, Hillsade NJ (eds.), Lawrence Erlbaum Associates Publishers, 1992

2. Gath A: The brothers and sisters of mentally retarded children. In: Children's Sibling Relationships: Developmental and Clinical Issues. Dunn J, Boer F, Hillsade NJ (eds.), Lawrence Erlbaum Associates Publishers, 1992

3. McHale SM, Gamble WC: Sibling relationships of children with disabled and nondisabled brothers and sisters. Developmental Psychology, 1989; 25(3): 421-29

4. Dyson L, Edgar E, Crnic K: Psychological predictors of adjustment by siblings of developmentally disabled children. American Journal on Mental Retardation, 1989; 94(3): 292-302

5. McHale SM, Gamble WC: Sibling relationships and adjustment of children with disabled brothers and sisters. Journal of Children in Contemporary Society, 1987; 19: 131-58

6. Bagenholm A, Gillberg C: Psychosocial effects on siblings of children with autism and mental retardation: a ppulationbased study. Journal of Mental Deficiency Research, 1991; 35: 291-307

7. Furman W, Buhrmester D: Children's perceptions of the qualities of sibling relationships. Child Development, 1985; 56: 448-61
8. Buhrmester D, Furman W: Perceptions of sibling relationships during middle childhood and adolescence. Child Development, 1990; 61: 1387-98

9. Kaminsky L, Dewey D: Siblings relationships of children with autism. Journal of Autism and Developmental Disorders, 2001; 31(4): 399-410

10. McHale SM, Harris VS: Children's experiences with disabled and nondisabled siblings: links with personal adjustment and relationship evaluations. In: Children's Sibling Relationships. Dunn J, Boer F, Hillsade NJ (eds.), Lawrence Erlbaum Associates Publishers, 1992

11. Stoneman Z: Childcare responsibilities, peer relations and sibling conflict: older siblings of mentally retarded children. American Journal of Mental Retardation, 1988; 93(2): 174-83

12. Abramovitch $\mathrm{R}$ et al: The influence of Down's syndrome on sibling interaction. Journal of Child Psychology and Psychiatry, 1987; 28: 865-79

113. Stoneman Z, Brody GH, McKinnon C: Naturalistic oservations of children's activities and roles while playing with their siblings and friends. Child Development, 1984; 55: 617-27

14. Brody GH: Sibling relationship quality: its causes and consequences. Annual Reviews Psychology, 1998; 49(1): 1-24 